\title{
AS MULHERES DESEJAM O PODER? ${ }^{\text {? }}$
}

\author{
Joel Birman*
}

\section{Resumo}

A intenção deste ensaio é pensar nas relações entre a mulher e o poder, no Ocidente, indicando a leitura psicanalítica sobre isso, a partir de um comentário inicial sobre a última eleição no Brasil.

Palavras-chave: mulher; poder; psicanálise.

\section{Abstract}

THE WOMEN WISH THE POWER?

The aim of this paper is to think about the relationships between the woman and the power in the Western tradition, pointing out the psychoanalytical interpretation, after some comments about the last Brazilian elections.

Keywords: woman; power; psychoanalysis.

\section{DESCONTINUIDADE NO DISCURSO FREUdiANO?}

Este ensaio pretende delinear, de maneira esquemática, as relações intrincadas que foram estabelecidas entre os temas da mulher e do poder. Estas relações constituem uma problemática crucial na contemporaneidade. As novas conquistas das mulheres, em termos de prestígio e de inscrições inéditas no espaço social, lançaram uma outra perspectiva para que se pudesse pensar sobre a história das

* Psicanalista; Professor Titular do Instituto de Psicologia da UFRJ; Professor Adjunto do Instituto de Medicina Social da UERJ; Pós-Doutorado em Psicanálise e Psicopatologia Fundamental na Universidade Paris VII; Pesquisador do CNPq; Pesquisador Associado do Laboratório de Psicanálise e Medicina; Diretor de Estudos em Letras e Ciências Humanas, Universidade Paris VII. 
relações tecidas até agora entre os gêneros no Ocidente. Isto é caracterizado pelo que Bordieu (1998) denominou de dominação masculina.

Contudo, a dita problemática já havia sido colocada em cena anteriormente, desde o final do século XVIII. No entanto, as respostas não foram convincentes. Além disso, as soluções não foram socialmente instituídas. O "blablablá" foi a sua tônica e o seu estilo. Daí por que a problemática em pauta foi relançada, em diversos contextos sociopolíticos e em diferentes tempos históricos, com cada vez maior radicalidade. Houve momentos de recuo e momentos de avanços, sem dúvida. A resultante maior disso, numa perspectiva histórica delineada no tempo da longa duração (Braudel, 1978), foi que os avanços sobrepujaram os recuos, de forma que na contemporaneidade as mulheres adquiriram efetivamente maior poder social. Quanto a isto, não existe qualquer dúvida.

No entanto, no que tange à tradição psicanalítica, a dita problemática foi colocada tragicamente em cena a partir de uma formulação concisa de Freud, num ensaio intitulado: "A feminilidade" (1933/1936). Neste ensaio, Freud se indagara sobre o que queriam as mulheres, afinal das contas. Num momento de franca perplexidade, no qual a inquietação estava também certamente presente, Freud não sabia mais responder a esta questão para ele até então trivial, qual seja, o que queriam as mulheres. Se até então Freud sabia responder a isso de maneira precisa e inequívoca, com efeito, esse não era mais o caso neste momento crucial de seu percurso teórico. Vale dizer, Freud tinha perdido todas as suas certezas e as dúvidas se disseminavam de maneira vertiginosa no seu discurso. Daí a perplexidade e a inquietação que tomavam Freud de corpo inteiro, de forma a indagar-se sobre o que queriam efetivamente as mulheres.

Primeiramente é preciso destacar, devidamente, que a indagação de Freud se inscrevia no registro do desejo. Como psicanalista era isso que lhe interessava efetivamente, sendo este o registro a ser colocado em cena. Daí a pergunta sobre o que querem as mulheres, afinal de contas. As respostas se avolumaram num redemoinho, que não se estabilizava num ponto fixo, de maneira a se configurar num repertório de respostas, ao mesmo tempo múltiplas e díspares, que conviviam numa condição de turbulência: o amor? $\mathrm{O}$ pênis? $\mathrm{O}$ filho? $\mathrm{O}$ analista? $\mathrm{O}$ poder? $\mathrm{Ou}$, então, a aquisição efetiva do poder pela mulher implicaria na aquisição conjunta de todos os atributos acima enumerados? Enfim, a perplexidade e a inquietação conjugados, na indagação sobre o desejo efetivo da mulher, marcaram a ferro e fogo o percurso teórico, ético e político de Freud.

A direção teórica, neste ensaio, pretende sustentar a hipótese de que a inquietante perplexidade de Freud se colocou num momento crucial do seu per- 
curso teórico. Momento que questionou a leitura inicial que formulara sobre a problemática da feminilidade e enunciou uma outra interpretação teórica sobre isso. Na primeira leitura, Freud legitimava a concepção moderna sobre a mulher, não obstante a presença ostensiva de marcas da concepção pré-moderna em seu discurso teórico. Na segunda leitura, em contrapartida, Freud rompeu com a interpretação inicial que enunciara e formulou que a feminilidade seria constituinte do ser. Vale dizer, se pela primeira leitura o masculino seria o modelo e a origem do feminino, pela segunda seria a feminilidade que delinearia a matriz constituinte do masculino e do feminino.

Assim, a perplexidade de Freud indicaria a sua descrença na solução inicial que forjara sobre isso, sendo conduzido na direção de uma outra leitura sobre a problemática da feminilidade. Freud realizou a desconstrução efetiva de seu paradigma teórico inicial, caminhando inequivocamente para a constituição decisiva de um outro paradigma teórico sobre a dita problemática.

No imaginário social brasileiro esta questão freudiana sobre o que querem as mulheres foi colocada em cena recentemente na televisão (TV Globo), em um seriado dirigido por Luis Fernando de Carvalho, exibido nos meses de novembro e de dezembro de 2010. De forma caricata e bem-humorada, mas com traços grotescos e impregnados de forte surrealidade, o seriado em pauta brincou com a indagação freudiana. A pergunta em surdina seria se a psicanálise ainda teria algo a dizer efetivamente sobre isso, isto é, se o discurso psicanalítico não seria já historicamente ultrapassado no que concerne à problemática da feminilidade.

No mundo pós-moderno, no qual as mulheres passaram a ocupar novas posições no espaço social e adquiriram inequivocamente outras inscriçôes no sistema de poder, a questão em pauta é certamente de uma enorme atualidade não apenas no campo internacional, mas também no Brasil. Isso porque a condição social da mulher esteve em foco na recente campanha eleitoral para a Presidência da República, ocupando até mesmo uma posição estratégica na cena da dita campanha.

Por isso mesmo, antes de me adentrar esquematicamente na genealogia (Foucault, 1971/1994) da diferença sexual e de gênero, nas suas relaçóes com a questão do poder, assim como inscrever a psicanálise na cena desta genealogia, vou começar por delinear como tais questôes reverberaram na recente campanha presidencial no Brasil. Parece-me que esta funcionou como um experimento crucial, no qual a temperatura das questóes colocadas pôde nos revelar a quantas andam as relaçôes da mulher e do poder na sociedade brasileira, na contemporaneidade. 


\section{Mulher e poder político no Brasil}

A problemática da relação estabelecida entre a mulher e o poder esteve no centro da última campanha presidencial no Brasil. Esta problemática foi evidenciada, até mesmo com certa dramaticidade, num determinado momento da campanha. Isto se deve não apenas ao fato de duas mulheres se apresentarem como candidatas, com sustentações políticas importantes, mas também porque a condição social da mulher foi colocada como tema crucial, especialmente na passagem do primeiro para o segundo turno da dita campanha. Foi justamente em decorrência disso que se evidenciou a dimensão dramática aludida acima.

Neste contexto, Dilma Rousseff e Marina Silva se colocaram como candidatas, representando as plataformas do Partido dos Trabalhadores (PT) e do Partido Verde (PV), respectivamente. A primeira venceu o primeiro turno com aproximadamente $47 \%$ dos votos e acabou por vencer as eleiçôes, no segundo turno, com $56 \%$ dos votos. A segunda angariou $20 \%$ dos votos no primeiro turno. Foi o patamar inesperado de votos conferido a Marina Silva no primeiro turno o que possibilitou a ida de José Serra do PSDB para o segundo turno, na medida em que este recebeu então $33 \%$ dos votos. A plataforma política da sustentabilidade, numa proposição que articulava desenvolvimento e ecologia, conferiu a Marina Silva o apoio dos jovens e das classes médias urbanas, que encararam decididamente o seu projeto de governabilidade como um indicador seguro de renovação política.

Porém o que foi significativo e surpreendente no resultado do primeiro turno é que $67 \%$ da população brasileira deu o seu voto para as candidatas mulheres. $\mathrm{O}$ discurso político de José Serra destacou que a oposição teria vencido o primeiro turno, pois, somados os seus votos com os de Marina Silva, que era também da oposição, isso totalizaria para essa $53 \%$ dos votos apurados. No entanto, se deslocando do registro estritamente partidário, que se polarizou entre o PT e o PSDB no segundo turno - até mesmo porque o PV não apoiou nenhum dos candidatos para o segundo turno -, o que se pode destacar é que a maioria esmagadora do eleitorado votou nas candidatas mulheres. Isto representou um deslocamento significativo no eleitorado, que teve desdobramentos imediatos na campanha do segundo turno.

Qual a razão de afirmar este deslocamento de maneira incisiva? Porque existia no imaginário social brasileiro, nos tempos anteriores à campanha eleitoral e nos quais as candidaturas estavam ainda se forjando no campo partidário, um discurso difuso de que o país deveria ser finalmente governado por uma mulher. Com efeito, a mídia disseminou esta mensagem inúmeras vezes, mesmo sem debatê-la 
de maneira sistemática. Isto indicou a presença deste desejo em parcela importante da população brasileira e nos formadores de opinião.

Qual era o argumento para isso? Não apenas de que os homens sempre exerceram a governabilidade e os impasses políticos do país continuavam presentes, mas principalmente de que a política estava sempre permeada pela rivalidade masculina e pela disputa regulada pelo tudo ou nada, de forma que a cena política seria colorida pela violência e pelo sangue. Seria preciso, então, transformar o estilo da governabilidade, retirando desse a sua marca agonística, de maneira que talvez a figura da mulher pudesse forjar um outro modelo para o exercício da política, constituindo outro paradigma para a governabilidade.

A maioria dos $67 \%$ dos votos, conferida para as duas mulheres no primeiro turno do pleito presidencial, confirmou de certa maneira o discurso difuso que circulava no imaginário brasileiro, de que seria preciso indicar uma mulher para a Presidência da República, contrariando assim a tradição masculina presente na política brasileira. Portanto, esta transformação no imaginário brasileiro, no que concerne à governabilidade do país, deve ser devidamente destacada, já que o Brasil é um país com marcas machistas importantes, como ocorre em geral nos países latinos e que são inscritos na tradição do catolicismo.

Em decorrência, pode parecer inicialmente inesperado o evidenciado no final do primeiro turno e no início do segundo. Assim, foram colocados na cena política da campanha temas até então não enunciados, em alto e bom som, mas provenientes de setores conservadores das Igrejas Católica e Evangélica. Com efeito, tanto a questão do aborto quanto a do casamento gay foram formuladas com bastante estridência, exigindo de ambos candidatos negociaçóes ostensivas com tais segmentos religiosos.

No que concerne a isso, o discurso eleitoral de José Serra incorporou muito mais os anseios conservadores destes segmentos religiosos do que o de Dilma Rousseff. Com efeito, Serra não apenas distribuiu santinhos para a população em portas de igrejas, como também posou para fotos carregando a escultura de Nossa Senhora de Aparecida. Ao lado disso, a esposa de Serra disse publicamente que Dilma Rousseff seria favorável ao aborto. Sendo assim, o eleitorado não poderia votar em alguém que fosse a favor da morte de crianças! $\mathrm{O}$ que isso colocou em evidência foi que a "baixaria correu solta", se disseminando de maneira ampla, geral e irrestrita no campo da campanha oposicionista, de forma que a Constituinte de 1988 foi não apenas rasgada mas também queimada em praça pública.

Pode-se depreender disso como o discurso da modernidade política no Brasil, no qual a pretendida eficiência governamental no plano da economia se conjugaria com a boa gestão do Estado, se articulou efetivamente com o discurso 
da pré-modernidade e do conservadorismo político, sem qualquer embaraço e até mesmo com certa facilidade. Numa das boas piadas que foram forjadas no segundo turno da campanha, por Dutra, que era Presidente do PT, foi dito com grande concisão significante que "Serra deixou definitivamente a AP e foi finalmente para a TFP".

Evidentemente, a candidata Dilma Rousseff fez também as suas negociações e concessóes com tais segmentos religiosos conservadores, mas nada que tenha atingido a falta de decoro e de pudor como ocorreu com José Serra, no que concerne às linhas de força da modernidade política brasileira. Com efeito, tratar o aborto como sendo uma questão de saúde pública, possibilitando que os serviços de saúde do Estado possam respaldar o cuidado médico das mulheres que são socialmente desfavorecidas em situação de gravidez - o que já ocorre fartamente na rede privada de saúde com a população socialmente favorecida -, se inscreve no campo efetivo na modernidade política no Brasil.

Pode-se dizer, portanto, que a plataforma eleitoral de tais grupos religiosos conservadores, assim como a acomodação diferencial dos dois candidatos face às demandas destes grupos, representou efetivamente um retrocesso político para o Brasil no que tange à separação política entre o Estado e a Igreja. Esta foi uma marca constitutiva da modernidade política no Brasil e também em escala internacional.

É preciso evocar ainda, para completar devidamente o quadro apocalíptico do retrocesso político que se constituiu no Brasil, que até mesmo o Papa Bento XVI entrou em cena na eleição brasileira, instigado que foi pelos setores conservadores da Igreja Católica. Assim, numa declaração inesperada, no apagar das luzes do segundo turno, o Papa defendeu a possibilidade de os prelados defenderem publicamente a candidatura que se adequasse melhor com os preceitos teológico-políticos da Igreja Católica. Desta maneira, o retorno ao tempo pré-moderno e pré-republicano da história brasileira foi sacramentado com chave de ouro. Nada poderia ter sido mais brilhante no terceiro ato da ópera política brasileira.

Contudo, a interferência do Papa foi em vão. De nada adiantou se queixar com o Papa, como se diz na gíria brasileira, pois naquela altura da campanha os votos para os dois candidatos já estavam cristalizados. Dilma Rousseff ganhou a eleição, apesar da oposição ferrenha dos setores conservadores do campo religioso.

Porém o que não se pode perder de vista é que a emergência de tais discursos conservadores, com a ênfase colocada nos temas que foram postos em destaque, não foi absolutamente inesperada. Isso porque a emergência destes discursos, no final do primeiro turno, foi uma reação ostensiva pela votação que foi conferida às candidatas mulheres, da parte de setores conservadores da sociedade brasileira. $\mathrm{O}$ que estava em pauta era uma outra representação social da mulher, na sua articulação 
íntima com o poder politico, assim como um outro lugar social a ser conferido às relações entre os gêneros no Brasil. É o que se verá em seguida.

\section{MATERNidAde, SOMbra do MASCULINo E SUSPENSÃo DE GÊNERO}

Deslocando-se do registro estrito da polarização eleitoral e examinando mais de perto os temas polêmicos que foram então evocados, na passagem do primeiro para o segundo turno do pleito, pode-se delinear, com certa facilidade, que a pauta não foi apenas a condição social da mulher, mas a relação entre os gêneros na sociedade brasileira.

Pode-se afirmar que tanto no que concerne à questão do aborto quanto no que se refere à interdição do casamento gay o que estava em cena, nos discursos religiosos conservadores, era o imperativo de uma representação tradicional dos gêneros e da conjugalidade. Com efeito, se a interdição do aborto visava sustentar a identificação da figura da mulher com a da mãe, no que concerne aos gays o que estava em pauta era a reafirmação das relações heterossexuais e a interdição dos laços homoeróticos. $\mathrm{O}$ que estava presente neste imaginário religioso sobre os gêneros era o enunciado da heterossexualidade compulsória - como nos disse Judith Butler em Problemas de gênero (1990) -, assim como a reafirmação da identidade feminina pelo viés da maternidade.

Estes enunciados identitários são tão poderosos e eloquentes na tradição brasileira que até mesmo o cantor e compositor Tim Maia, caracterizado que era por uma certa transgressão face a certas normas sociais, se inscreveu decididamente no campo destes enunciados. Quando cantava, como um bardo supostamente transgressor, que "vale tudo, menos homem com homem e mulher com mulher", Tim Maia ressoava no seu estribilho irônico os preceitos tradicionalistas sobre as relações entre os gêneros no Brasil. Vale dizer, o genial Tim Maia não se esqueceu jamais de sua experiência evangélica, pois mesmo nas suas divertidas esbórnias reafirmara a leitura moderna sobre as relações entre os gêneros.

Esta identificação da figura da mulher com a da mãe foi uma construção antropológica estritamente moderna, como veremos posteriormente neste ensaio. O corolário desta representação social da mulher é que esta ficaria subsumida à representação social do homem, como o seu complemento. Porém foi no campo desta identificação maternal da mulher que se constituíram duas modalidades de inscrição da mulher no campo político da modernidade. Pela primeira inscrição, a figura da mulher seria uma simples sombra e o negativo da figura do homem, isto é, a sua representante efetiva. Pela segunda, em contrapartida, a figura da mulher 
sofreria uma transformação radical, pois seria agora masculinizada. Vale dizer, nesta direção a figura da mulher seria efetivamente masculinizada, assumindo um estilo francamente viril.

No que se refere à mulher como sombra do homem, pode-se dizer que Evita Perón, na Argentina, foi a sombra de Perón, por um lado, e o seu complemento feminino por outro. Por isso mesmo, foi a mulher-esposa de Perón, mas também a representação da mãe na tradição política Argentina. Para a estratégia política de Perón, era fundamental que Evita assumisse a função da mãe da nação. Ainda insistindo nesta tradição política, Cristina Kirchner foi a sombra de seu marido Néstor, que era quem governava efetivamente o país nos bastidores da Casa Rosada. Ao que tudo indicava, Néstor Kirchner pretendia retornar ao poder presidencial na nova eleição, mas com a sua morte inesperada sepultou a sua pretensão e, ao que tudo indica, deixou Cristina Kirchner em apuros.

Perón nos trouxe também uma outra sombra de sua figura com Isabelita Perón. Isso porque, sem que esta tivesse qualquer percurso político e governamental, Perón a elegeu Presidente da República para ela ser a sua representação formal e a sua sombra. Contudo, a sua morte desarticulou o seu esquema de representação, tendo Isabelita que se virar com o exercício da governabilidade. No entanto, a figuração da sombra aqui não se articulava com a figura da mãe, pois Isabelita era uma dançarina de cabaré no Panamá, onde Perón a resgatou para a condição de esposa e para a glória da política na Argentina. Portanto, mesmo que Isabelita não tenha conseguido ser a mãe da nação Argentina, como Evita foi e como Perón pretendia ressuscitar o mito desta, Isabelita era inequivocamente a sombra do caudilho argentino. No entanto, com a morte de Perón, Isabelita foi para o cadafalso político, o que possibilitou a sangrenta ditadura militar na Argentina.

Um outro exemplo memorável de estadista-mulher como sombra do homem foi Indira Gandhi, que governou a Índia por um longo período. Ela adquiriu uma grande notoriedade internacional, pois foi uma das lideranças dos países não-alinhados nos tempos da Guerra Fria. No entanto, Indira Gandhi era a sombra de uma importante casta masculina, sendo então a representante desta.

No registro agora da figura da mulher viril, no campo político, a Primeira Ministra inglesa Margareth Thatcher foi uma paródia da figura masculina, sendo por isso mesmo ironicamente denominada de "a dama de ferro". A violência estridente desta figura foi memorável, colocando até mesmo os homens na sua sombra, na caricatura ostensiva que foi da figura masculina.

Finalmente, pode-se evocar a existência de governantes-mulher que colocaram em estado de suspensão a sua identidade sexual, não seguindo nem o padrão mascu- 
lino nem tampouco o feminino. Este foi o caso de Bachelet no Chile, quando foi Presidente da República. Este é ainda o caso, enfim, de Ângela Merkel, dirigente política atual da Alemanha.

Em ambas, a questão da identidade de gênero não está efetivamente presente na configuração de sua personagem pública; situam-se em uma modalidade de no man's land no que concerne à identidade sexual, isto é, nem homem nem mulher. O que estaria em pauta, aqui, em filigrana, seria a formulação ostensiva de que o exercício do poder político não implicaria absolutamente na identidade de gênero e que seria esta a questão que estaria hoje em pauta. Enfim, a inscrição da questão de gênero no campo da política seria nesta perspectiva historicamente superada.

Será isso mesmo? Será este o caminho do novo paradigma de governabilidade? Somente o futuro poderá nos responder a isso com consistência.

\section{GOVERNAR É CUIDAR?}

Onde se inscreveriam as candidatas brasileiras à Presidência da República no que concerne a isso? No caso de Marina Silva, não me parece que a identificação como sombra do masculino esteja presente na construção de sua imagem pública, nem tampouco a figura da virilização. Ao contrário, Marina Silva forjou o seu percurso político em associação inicial com Chico Mendes, vindo da Amazônia para Brasília, sempre marcando a sua singularidade. Bastante discreta na ocupação da cena política, numa atuação sem estardalhaço e sem espetacularização, mas firme na sustentação de seus pontos de vista. A sua personagem pública evidencia elegância, mas sem cultuar a imagem tradicional da mulher embonecada, como foi o caso de Isabelita Perón e é ainda hoje o caso de Cristina Kirchner. Assim, a maquiagem é quase ausente na composição pública da imagem de Marina Silva, evidenciando assim uma figura outra da feminilidade.

Por outro lado, Dilma Rousseff é mais polivalente. É representada pela mídia como uma mulher dura como Thatcher e também como sombra de Lula, que almejaria voltar à Presidência da República na próxima eleição (Dilma estaria apenas esquentando a cadeira presidencial para o futuro retorno triunfal de Lula ao poder). Entretanto, Dilma indica que não é uma cópia de Lula. Se incorpora algumas indicações deste na composição de seu ministério inicial, com efeito, tem também as suas escolhas próprias.

No que concerne a isso, o ministério de Dilma Rousseff foi composto pela presença de inúmeras mulheres, delineando uma face feminina para o poder polí- 
tico. Além disso, na posse da nova Presidente foram as mulheres e não os homens quem compuseram o aparato de segurança no cortejo presidencial em carro-aberto, numa cenografia eloquente da inscrição da figura da mulher no poder político do Brasil. Porém o mais importante não é isso. É preciso evocar ainda a existência de dois tópicos cruciais na eleição de Dilma Rousseff. Antes de mais nada, sua candidatura foi apresentada como decorrência de o Brasil ter tido, com Lula, um Presidente socialmente humilde, de origem operária. Assim, Dilma Rousseff viria representar agora um outro segmento social que nunca tinha sido contemplado, até então, pelo poder; isto é, o das mulheres. Enfim, após a figura do operário, surge a de uma mulher, numa nova roda da fortuna, que subverteria definitivamente a tradição política brasileira. Em seguida, é preciso destacar que Lula remanejou o imaginário político ocidental nesta campanha presidencial. Isso porque passou a declinar o verbo governar com o verbo cuidar. Vale dizer, Lula transformou uma tradicional prática social estritamente masculina, como a política, com as marcas do feminino, pela inscrição efetiva da ideia de cuidado no campo da política. Podese sempre dizer que o feminino foi introduzido aqui pelo registro tradicional da maternidade e pela retórica masculina, mas é indiscutível que isso provocou um remanejamento efetivo no imaginário político.

Pode-se afirmar que Lula foi o porta-voz direto ou indireto de um discurso feminista recente, que pela contraposição das figuras do masculino e do feminino inscreveu o campo do masculino no registro da predação e o campo do feminino no registro do cuidado (Badinter, 2005). Por isso mesmo, neste discurso feminista, a governabilidade se conjugaria definitivamente com o cuidado, como alicerce que seria de um novo paradigma político no Ocidente.

Resta saber como o futuro vai infletir este conjunto de direçôes díspares, indicadas pelo registro do feminino e pela condição social da mulher na política brasileira. Isto é, como as diferentes linhas de força deste mosaico vão forjar ou não novas composições no campo do poder. Uma outra modalidade de governabilidade, declinada com o cuidado, vai se constituir efetivamente no futuro? A figura da mulher-governante vai finalmente se emancipar da figura do homem, seja no registro da sombra do masculino, seja sob a forma da maternidade e da virilização? Somente o futuro poderá nos oferecer respostas seguras para isso.

Porém é preciso que nos voltemos agora para uma leitura das relações da figura da mulher com a questão do poder, no Ocidente, de maneira esquemática, para que possamos inscrever o que dissemos acima sobre o lugar da mulher na política brasileira recente numa perspectiva histórica mais ampla. Além disso, a leitura psicanalítica do feminino será igualmente inscrita neste cenário histórico e genealógico. 


\section{Diferença sexual}

A passagem histórica do final do século XVIII para o início do século XIX incidiu de maneira significativa na representação social da mulher, delineando para esta uma outra relação com o poder. Foi neste contexto sociopolítico, com efeito, que a figura da mulher adquiriu uma certa posição no campo da governabilidade. Entretanto, o que conseguiu ficou certamente muito aquém de sua pretensão. $\mathrm{O}$ que a figura da mulher reivindicara era a plena igualdade de direitos com a figura do homem, no espaço público e no espaço privado. Porém a governabilidade adquirida pela mulher ficou restrita ao espaço privado da família (Birman, 2001).

Assim, se a antiga condição de inferioridade ontológica da mulher, constituída na Antiguidade e que era ainda imperante no século XVII, foi efetivamente relativizada, a minoridade feminina permaneceu no campo do espaço público (Laqueur, 1992). Com efeito, as mulheres não podiam votar e não podiam igualmente exercer funções públicas, devendo então se restringir às condições sociais de esposa e de mãe. A luta pelo sufrágio feminino e pela ocupação de outras posições sociais, além destas últimas, direcionaram as lutas feministas desde a aurora do século XIX (Birman, 2001).

Porém qual foi o poder relativo que foi adquirido pelas mulheres neste contexto sociopolítico, afinal das contas? As mulheres pretendiam adquirir a igualdade de direitos com os homens, tal como foi sustentado pelo projeto de Iluminismo ao longo do século XVIII, tornando politicamente insustentável a concepção da inferioridade ontológica da mulher face ao homem formulada na Antiguidade. A figura da mulher foi, então, reconfigurada pelo viés da maternidade. A especificidade ontológica da mulher seria definida pela condição efetiva de ser mãe, diferenciando-se então da figura do homem. Neste contexto, foi constituído o mito do amor materno (Badinter, 2005). Portanto, ser mãe foi a maneira pela qual uma solução de compromisso foi então estabelecida entre a tradição antiga da inferioridade ontológica feminina e o discurso moderno da igualdade de direitos enunciado pelo Iluminismo (Laqueur, 1992).

Nesta perspectiva, não se poderia mais dizer que as mulheres seriam inferiores aos homens por essência e natureza. Ao contrário, seriam a anatomia e a fisiologia femininas, com seus desdobramentos para o registro moral, que as destinavam inevitavelmente à maternidade. Com efeito, mais próximas do registro da nature$z a$ do que do registro da cultura, as mulheres teriam um desenvolvimento maior do registro do sentimento do que do registro da razão. Seria por conta disso que estariam fadadas à maternidade e ao espaço privado da família, em oposição aos 
homens, que iriam para o espaço público pela maior presença da racionalidade no seu ser (Birman, 2001).

Constituiu-se, assim, o discurso moderno da diferença sexual, pelo qual os sexos masculino e feminino seriam diferenciados por natureza, mas no qual a diferenciação não implicaria efetivamente numa hierarquia ontológica entre as condições masculina e feminina. $\mathrm{O}$ discurso da diferença sexual se opunha ao discurso do sexo único forjado na Antiguidade, em que a dita hierarquia ontológica entre os sexos se enunciou e a inferioridade ontológica da mulher face ao homem se instituiu, conforme nos ensinou Laqueur (1992) em A fábrica do sexo. Seria em decorrência da diferença essencial inscrita na natureza e de suas derivaçōes no registro moral que as figuras do homem e a da mulher teriam funções e inserções sociais diferenciadas.

É preciso evocar ainda que a dita restrição efetiva à expansão social da mulher no registro do espaço público, em oposição à figura do homem, foi conjugada à constituição do biopoder e da biopolítica (Foucault, 1976). Segundo este mesmo autor, a qualidade de vida da população foi alçada à condição de fonte maior de riqueza do Estado-nação, não se baseando mais fundamentalmente a dita riqueza nem na extensão territorial do Estado, nem tampouco nos recursos materiais existentes no seu território na modernidade.

O que era a qualidade de vida da população? Quais eram os seus indicadores? Nada mais nada menos do que a saúde e a educação. Vale dizer, um Estado-nação seria rico se pudesse contar com uma população saudável e bem-educada; isto é, se fosse capaz de capitalizar produtivamente a extensão territorial e os recursos materiais nessa existentes. Em decorrência disso, foi instituída não apenas a $e d u$ cação obrigatória desde a aurora da modernidade, mas também a medicalização disseminada do espaço social (Foucault, 1976).

A medicalização instituída na modernidade implicou não apenas a substituição do ideário da salvação, constituído na antiga tradição do Cristianismo, pelo da cura (Foucault, 1963), mas também a promoção do biopoder e da biopolítica. Isso significa que a preocupação com a constituição biológica da espécie passou a se inscrever no registro do poder e da governabilidade (Foucault, 1976), tendo como perspectiva a produção efetiva da qualidade de vida da população como signo irrefutável que seria isso da riqueza do Estado-nação.

Foi por conta disso que a infância se transformou num momento do desenvolvimento vital, pois seria nela que as boas condições de saúde e de educação seriam então instituídas desde as origens. Com efeito, a figura da criança seria a condensação do capital simbólico e do capital econômico da Nação, na medida em que ter crianças saudáveis e bem-educadas seria a garantia da futura riqueza do 
Estado (Freud, [1914] 1969). Enfim, como disse Freud em "Para introduzir o narcisismo", na modernidade a criança assumiu efetivamente a condição de soberania, isto é, a criança seria "a sua majestade, o bebê" (Birman, 2001).

Foi em decorrência disso que, na modernidade, não apenas a figura da mulher foi configurada como mãe, como também foi alçada ao campo da governabilidade. Isso porque, além de passar a realizar a gestão do espaço familiar, a figura da mulher teria que articular a conjunção da prole com as instituições médica e escolar, em nome sempre da promoção da qualidade de vida da população (Birman, 2001).

\section{SEXo ÚnICO}

Na tradição pré-moderna, a figura da mulher não tinha este poder. Ela ficou restrita à condição de gestação das crianças, isto é, a mulher era apenas uma parideira. Isso evidencia a outra dimensão da dita inferioridade ontológica da mulher face à figura do homem, na medida em que este era muito mais importante do que aquela no ato da concepção. Vale dizer, a figura do homem era ativa no ato da concepção, enquanto a da mulher era passiva e receptiva, como enunciou Aristóteles na obra Da geração e da corrupção (Aristóteles, 1967). Em seguida, na tradição romana esta formulação foi relançada por Galeno, que constituiu ainda o paradigma do sexo único, que perdurou como modelo de relação entre os sexos até o século XVII (Laqueur, 1992).

Assim, no paradigma do sexo único existiria total similaridade entre os diferentes componentes anatômicos dos órgãos genitais e reprodutores nas figuras do homem e da mulher. Daí a concepção da existência do sexo único na Antiguidade, diferente então da concepção moderna da diferença sexual, na qual não existiria qualquer similaridade e equivalência morfológicas entre o homem e a mulher. Contudo, na concepção antiga do sexo único a exterioridade anatômica masculina se contraporia à interioridade feminina pela maior presença do humor quente no corpo masculino. Portanto, a oposição masculino/feminino seria regulada pela diferença dos humores nos corpos do homem e da mulher. Enfim, a exteriorização morfológica masculina, conjugada à presença do humor quente, implicaria numa atividade masculina; enquanto que a invaginação morfológica feminina implicaria na passividade (Laqueur, 1992).

Estaria delineada, assim, a superioridade ontológica da figura do homem face à da mulher. Sendo assim, a figura da mulher poderia ser transformada na do homem, desde que o humor quente se fizesse presente no corpo daquela. Porém a transformação oposta seria impossível, pois na concepção filosófica presente 
na Antiguidade para a qual o Cosmo seria hierarquizado, o polo inferior poderia sempre se transformar no superior por um processo de aperfeiçoamento, mas o oposto seria inconcebível. Relança-se também desta maneira, enfim, a inferioridade ontológica do feminino face ao masculino pela concepção hierárquica do Cosmos (Laqueur, 1992).

Foi este paradigma do sexo único, que perdurou da Antiguidade até o século XVII, que ficou insustentável face ao discurso da igualdade de direitos sustentado pelo Iluminismo (que culminou com o advento da Revolução francesa) (Laqueur, 1992). Com efeito, não se poderia mais falar de inferioridade e de superioridade, no que concerne à problemática de gênero, quando se enunciava o princípio da igualdade entre todos os homens, sejam estes do sexo masculino ou feminino. Por isso mesmo, a concepção da diferença sexual foi forjada, enunciando a existência de diferenças essenciais de natureza entre as condições masculina e feminina, de maneira a manter a subalternidade feminina face ao masculino, mas fundada agora numa leitura diferencial da natureza. Esta transformação, como vimos acima, se inscreveu numa matriz biopolítica, que ofereceu um novo poder relativo (que não possuía anteriormente) para a figura da mulher, reconfigurada que foi agora como mãe.

\section{Do FALO À FEMINILIDADE}

Foi no campo do paradigma moderno da relação entre os gêneros que se inscreveu a psicanálise no tempo de sua emergência histórica, na passagem do século XIX para o século XX. Porém, na sua leitura sobre a diferença sexual, Freud inscreveu também o paradigma teórico do sexo único. Para isso, contudo, se deslocou do registro da anatomia para o da subjetivação. Isso implica em dizer que Freud enunciou diferentes discursos sobre a feminilidade, formulando diversas relações entre a figura da mulher e do poder.

Antes de mais nada, ao se centrar inicialmente sobre a histeria, Freud evidenciou que uma crítica incisiva sobre a diferença sexual estava sendo colocada em pauta. As mulheres colocavam em cena o desejo de ser homem e mulher ao mesmo tempo na relação sexual, através da crise histérica (Freud, [1909] 1973). Com isto, implodiria o paradigma moderno da diferença sexual. Além disso, Freud enunciava que a articulação da gestão familiar e dos cuidados dos filhos exigia um trabalho feminino bem maior do que o masculino, pelas satisfações restritas que isso promovia (Freud, [1908] 1969). Por isso mesmo, o masoquismo da figura da mulher estaria inscrito nesta construção social e política centrada na maternidade. 
Seria este masoquismo feminino que estaria na base da melancolia das mulheres (Freud, [1925] 1969). Assim, a histeria e a melancolia seriam duas formas opostas de as mulheres se posicionarem face ao paradigma da diferença sexual. Se pela histeria as mulheres buscavam virar a mesa e criticar o paradigma da diferença sexual e o poder masculino, pela melancolia, em contrapartida, as mulheres desistiam do embate e se submetiam masoquisticamente ao poder masculino. Com efeito, se o desejo seria o impulsionador da experiência psíquica da histeria, na melancolia o desejo entraria no estado de suspensão e o masoquismo consumiria inteiramente o ser da mulher.

Porém estas modalidades clínicas de descrição do sofrimento feminino se inscreveram no discurso inicial de Freud sobre a feminilidade. Contudo, este discurso teórico entrou em crise no percurso freudiano, quando este formulou a pergunta sobre o que querem as mulheres, afinal das contas? Foi a partir desta interrogação que o discurso freudiano pôde formular um outro discurso sobre a feminilidade no final do seu percurso teórico.

Quais foram então estes discursos teóricos que Freud formulou, em dois tempos diferentes de seu percurso na psicanálise, sobre a figura da mulher e a feminilidade? Num primeiro tempo, o discurso freudiano concebeu a sexualidade centrada originariamente no registro do masculino, fundado que seria na sexualidade perverso-polimorfa e na atividade (Freud, [1908] 1969), de forma que libidinalmente os homens e as mulheres estariam originariamente no registro masculino. Estaria aqui, em Freud, o eco da concepção antiga do sexo único, enunciado agora em torno da figura do falo (Freud, [1923] 1969). Contudo, as mulheres teriam que perder o falo, identificado com o pênis, para aceder finalmente à feminilidade. Enfim, a condição feminina acabaria por confluir para a condição da maternidade (Freud, [1925] 1969).

Contudo, uma parcela das mulheres resistia a esta perda do falo e à condição maternal, seja pela inibição sexual, seja pela virilização (Freud, [1925] 1969). Vale dizer, se elas não pudessem ter o falo, prefeririam então não ter qualquer erotismo, ou então prefeririam permanecer fálicas, com a assunção da posição viril.

$\mathrm{Na}$ lógica libidinal desde paradigma teórico, centrado que era na figura do falo, a figura da mulher poderia perder a condição fálica pela assunção efetiva da maternidade. Isso porque, nesta descrição teórica de Freud, a figura da criança seria equivalente ao falo. Assim, a mulher perderia o falo por um lado para recuperá-lo pelo outro (Freud, [1925] 1969) para atingir a condição de plenitude narcísica no seu ser.

Contudo, levado pela perplexidade na sua indagação sobre o que querem as mulheres, o discurso freudiano formulou um outro discurso teórico sobre a 
feminilidade e a relação entre os gêneros. Assim, em "Análise com fim e análise sem fim", ensaio escrito em 1937, Freud inscreveu a feminilidade na origem e não mais a masculinidade. O que isso quer dizer, afinal das contas?

Nada mais nada menos que existiria uma feminilidade originária, face à qual tanto a construção psíquica masculina quanto a feminina se defenderiam. A dita feminilidade seria uma experiência da ordem do horror e da inquietude. Em decorrência disso, a condição masculina e a condição feminina seriam defesas face à feminilidade originária, defesas essas construídas igualmente pela lógica do falo.

Portanto, o discurso freudiano deu um giro completo entre a primeira concepção da relação entre os gêneros e a segunda concepção, pois, se inicialmente o registro do masculino estaria na origem, posteriormente a origem estaria no registro da feminilidade. Com efeito, se pela primeira concepção a figura da mulher teria que perder o falo para recuperá-lo posteriormente pela figura da criança, pela segunda concepção a feminilidade seria originária tanto para o homem quanto para a mulher (Freud, [1937] 1992).

Supomos que com as novas condições da mulher, forjadas pelo movimento feminista desde os anos 60 e 70 - em que as mulheres saíram definitivamente do espartilho da maternidade e buscaram novas formas sociais de ser além da restrita condição materna -, o segundo discurso freudiano sobre a feminilidade é mais adequado aos novos ares do tempo. Podemos dizer ainda que o discurso freudiano, na sua segunda versão teórica sobre a relação entre os gêneros, foi um prenúncio do esgotamento ético, político e teórico do paradigma moderno, assim como uma formulação incisiva em direção de uma outra leitura pós-moderna sobre a relação entre os gêneros. Enfim, esta reviravolta teórica apenas se deu quando Freud foi tomado inteiramente pela perplexidade diante da formulação: o que querem as mulheres, afinal das contas?

\section{REFERÊNCIAS}

Aristóteles. (1967). De la génération et de la corruption. Paris: Belles Lettres.

Badinter, E. (1980). L'amour en plus, histoire de l'amour maternel (XVII' au XX'e siècle). Paris: Flammarion.

Badinter, E. (2005). Rumo equivocado. O feminismo e alguns destinos. Rio de Janeiro: Civilização Brasileira.

Birman, J. (2001). Gramáticas do erotismo. A feminilidade e suas formas de subjetivação em psicanálise. Rio de Janeiro: Civilização Brasileira.

Bourdieu, P. (1998). La domination masculine. Paris: Seuil. 
Braudel, F. (1978). História e ciências sociais. A longa duração. In: Braudel. F. Escritos sobre a história (pp. 41-77). São Paulo: Perspectiva.

Butler, R. (1990). Gender trouble: feminism and the subversion of identity. New York: Routledge \& Hall, Inc.

Foucault, M. (1963). Naissance de la clinique. Paris: PUF.

Foucault, M. (1976). La volonté de verité. Paris: Gallimard.

Foucault, M. (1971/1994). Nietzsche, la généalogie, l'histoire. Dits et écrits (v. II, pp. 145-172). Paris: Gallimard.

Freud, S. (1905/1962). Essais sur la théorie de la sexualité. Paris: Gallimard.

Freud, S. (1908/1969). La morale sexuelle "civilisée" et la maladie nerveuse des temps modernes. La vie sexuelle (pp. 28-46). Paris: PUF.

Freud, S. (1909/1973). Considérations génerales, sur l'attaque hystérique. Névrose, psychose et perversion (pp. 161-165). Paris: PUF.

Freud, S. (1914/1969). Pour introduire le narcissisme. La vie sexuelle (pp. 81-105). Paris: PUF.

Freud, S. (1923/1969). L'organisation génitale infantile. La vie sexuelle (pp. 113-116). Paris: PUF.

Freud, S. (1925/1969). Quelques conséquences psychiques de la différence anatomique entre les sexes. La vie sexuelle (pp. 123-132). Paris: PUF.

Freud, S. (1933/1936). Nouvelles conférences sur la psychanalyse. Paris: Gallimard.

Freud, S. (1937/1992). L'analyse avec fin et l'analyse sans fin. Résultats, idées, problèmes. (v. 2, pp. 231-268). Paris: PUF.

Laqueur, Th. (1992). La fabrique du sexe. Essai sur le corps et le genre en Occident. Paris: Gallimard.

\section{Notas}

1 Este texto foi escrito a partir das notas que me orientaram na conferência realizada em novembro de 2010 no seminário intitulado "Afinal, o que querem as mulheres?", organizado pelo Departamento de Psicologia da PUC/RJ e pela Globo Universidade.

Aceito para publicação em 28 de outubro de 2010 